Available online at www.journal.unrika.ac.id

Jurnal KOPASTA

Jurnal KOPASTA, 3 (1), (2016) 40 - 52

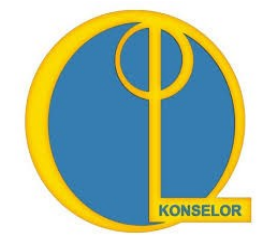

\title{
Deskripsi Masalah Mahasiswa Yang Sedang Menyelesaikan Skripsi
}

\author{
Nur Etika \& Wilda Fasim Hasibuan*
}

Division of Counseling and Guidance, University, of Riau Kepulauan, Batam

\begin{abstract}
Abstrak
Mahasiswayang sedang menyelesaikanskripsisering kali mengalami berbagai hambatan, sehingga secara tidak langsung hal tersebut menghambat mahasiswa dalam menyelesaikan skripsi. Masalah-masalah tersebut dapat berupa seperti pada penentuan judul skripsi, kurangnya referensi, kurangnya waktu, rasa malas mengerjakan skripsi, kurang motivasi, dosen yang susah ditemui, susah membagi waktu, kelelahan, waktu istirahat tidak cukup, kurang biaya dan tidak konsentrasi dalam proses penyelesaian skripsi. Tujuan penelitian ini adalah untuk dapat mendeskripsikan apa saja masalah yang dialami oleh mahasiswa tingkat akhir yang sedang menyelesaikan skripsi.
\end{abstract}

Keyword: masalah mahasiswa, skripsi

\section{Pendahuluan}

Hampir setiap manusia di dunia memiliki masalah, baik masalah itu besar maupun kecil. Adakalanya seseorang akan sangat peka menghadapi atau menanggapi masalah, tetapi sebaliknya ada seseorang yang masih tetap tabah walaupun sedang mengalami masalah yang berat dan serius. Maka seberapa berat penderitaan individu dalam mengalami masalah, tergantung kepada individu itu sendiri dalam menanggapi masalah yang dialami, karena masalah yang dialami setiap individu berbeda satu dengan lain. Tetapi pada umumnya masalah memang mengganggukehidupan. Masalah yang umum dan yang paling sering terjadi di Universitas adalah pada masalah mahasiswa tingkat akhir (dalam Pujosuwarno 1994).

Kesulitan-kesulitan saat penyusunan skripsi oleh mahasiswa sering dirasakan sebagai suatu beban yan berat, akibatnya kesulitan-kesulitan yang dirasakan tersebut berkembang menjadi sikap yang negatif yan akhirnya dapat menimbulkan suatu kecemasan dan hilangnya motivasi.Sehingga menyebabkan mahasiswa menunda menulis skripsinya bahkan ada yang memutuskan untuk tidak menyelesaikanskripsinya (dalam Hariwijaya 2008). Berdasarkan latar belakang masalah di atas dalam penelitian ini dapat dirumuskan menjadi "bagaimana deskripsi masalah mahasiswa yang sedang menyelesaikan skripsi?".

\section{Metode Penelitian}

Jenis penelitian ini adalah penelitiankualitatif deskriptif. Hal ini dinilai tepat karena dengan data kualitatif dapat mengikuti dan memahami alur peristiwa secara kronologis dalam Sugiyono (2012). Menurut Patilima (2005) menyatakan bahwa penelitian kualitatif deskriptif yaitu penelitian yang berusaha untuk menuturkan pemecahan masalah yang ada sekarang berdasarkan data-data, menganalisis dan

* Nur Etika E-mail addres: icha.bk@gmail.com

* Wilda Fasim Hasibuan Telp. 081390001757 E-mail addres: wildahasibuan@hotmail.com 
mengimpretasikannya. Dengan tujuan untuk mengetahui gambaran dan faktor-faktor apa saja yang menyebabkan mahasiswaitu mengalami kesulitan dalam menyelesaikan tugas akhir studinya. Pada penelitian ini peneliti melakukanlangkah-langkah pengumpulan data dengan cara menggunakan teknik observasi nonpartisipan, wawancara tidak terstruktur dan wawancara semiterstruktur apabila diperlukan.

Teknik analisis data dalam penelitian kualitatif, data yang diperoleh dari berbagai sumber dengan menggunakan teknik pengumpulan data yang bermacam-macam dan dilakukan terus menerus sampai datanya valid. Model analisis data dalam penelitian ini mengikuti konsep yang diberikan Miles and Huberman (1984). Miles and Hubermen(dalam Sugiyono 2013) mengungkapkan bahwa aktifitas dalam analisis data kualitatif dilakukan secara interaktif dan berlangsung secara terus-menerus pada setiap tahapan penelitian sehingga sampai tuntas. Dalam penelitian ini, untuk mendapatkan data yang kredibel peneliti menggunakan model analisis data dari Miles and Huberman (1984) yaitu dengan menggunakan reduksi data, penyajian data dan verifikasi atau penyimpulan data sehingga data yang diperoleh dapat dikatakan kredibel karena dilakukan secara berulang-ulang dan terus-menerus sehingga mendapatkan hasil yang dipercaya dan benar adanya.

\section{Hasil Penelitian dan Pembahasan}

Mahasiswa yang sedang mengerjakan skripsi mempunyai berbagai macam masalah. Berdasarkan pengamatan awal yang peneliti lakukan menunjukkan adanya beberapa masalah yang timbul dalam penyelesaian skripsi. Peneliti melakukan observasi awal pada enam mahasiswa menyatakan dalam proses mengerjakanskripsi mengalami kesulitan.

Berdasarkan hasil wawancara yang dilakukan pada bulan Maret-April,peneliti menyimpulkan kesulitannya yaitumereka mengalami banyak masalah seperti susah tidur, hilangnya nafsu makan, sakit, kurangnya waktu istirahat, kekurangan biaya, kurangnya motivasi, terkadang masalah pribadi mengganggu pikiran sehingga tidak konsentrasi dalam pembuatan tugas skripsi. kesulitan pada mengatur waktu, kelelahan, rasa malas mengerjakan skripsi, belum lagi dosen pembimbing yang kadang susah untuk ditemui, belum jelasnya lapangan pekerjaan (masa depan) yang akan dituju, tuntutan dari orang tua agar cepat menyelesaikan skripsi. kesulitan dalam penyusunan skripsi diantaranya kesulitan dalam menyusun perumusan masalah, menentukan judul, mengkonsep isi skripsi, teknik penulisan, isi, metode penelitian yang digunakan, dan kurangnya referensi, serta kesulitan dalam menuangkan tulisan ke dalam naskah skripsi.

Berdasarkan pengamatan akhir yang penulis lakukan menunjukkan adanya beberapa masalah yang timbul dalam penyelesaian skripsi. Peneliti melakukan observasi pada dua mahasiswa menyatakan dalam proses mengerjakan skripsi mengalami kesulitan. Berdasarkan hasil wawancara dengan kedua subjek dan tujuh informan yang berasal dari teman, dosen dan saudara subjekpeneliti menyimpulkan kesulitannya yaitu:

\section{Penentuan Judul Skripsi}

Penentuan pada judulskripsi,mahasiswa mengalami beberapa kesulitan untuk mendapatkan permasalahan yang akan dijadikan sebagaijudul penelitian. Salah satu kesulitannya adalah bingung mencocokkan antara variabel satu dengan variabel lainnya. Karena setiap Jurusan pasti berbeda pada penentuan variabel dijudul penelitiannya. Salah satu contohnya di Jurusan Matematika yang membuat suatu judul penelitian yang dua variabel bebas dan satu variabel terikat. Sehingga sebagian mahasiswa mencari alternatif lain untuk mendapatkan judul dengan cara mencari judul di internet. Dari hasil wawancara yang dilakukan pada tanggal 27 April 2015 subjek pertama mengalami kebingungan dalam menentukan judul skripsinya yang telah dijelaskan diatas. Lalu dia mencari judul di internet dan mengubah serta menggabungkannya sehingga menjadi satu judul penelitian.

\section{Kurang Referensi}

Kurangnya referensi diakibatkan oleh kurangnya persediaan buku-buku yang menyangkut dalam penelitiannya,sehingga menyebabkan mahasiswa kesulitan dalam mencari referensi. Dari hasil wawancara subjek pertama pada awalnya mengalami kesulitan pada pencarian referensi yang akan dijadikan sebagai pedoman pada penelitiannya. Tetapi sekarang subjek sudah mendapatkan referensi dengan cara browsingdi internet, ada juga mendapatkan bahan materi dari perpustakaan serta juga dapat meminjam buku dari teman. Walaupun referensinya sedikit yang didapat, tetapi sudah sekarang sudah bisa untuk menyusun skripsi.

\footnotetext{
* Nur Etika E-mail addres: icha.bk@gmail.com

* Wilda Fasim Hasibuan Telp. 081390001757 E-mail addres: wildahasibuan@,hotmail.com
} 


\section{Kurangnya Waktu Mengerjakan Skripsi}

Kurangnya waktu untuk kuliah maupun mengerjakan skripsi dikarenakan jam kerja yang terbentur dengan jam kuliah sehingga akibatnya kuliah terbengkalai dan tugas pun tidak dikerjakan. Pada subjek pertama yaitu AS dan subyek kedua yaitu FM, mengalami masalah pada kurangnya waktu dalam penyusunan skripsi karena pada subjek pertama jam kerjanya dari jam 08.00 WIB-17.00 WIB, untuk berangkat saja kuliah terlambat beberapa menit. Sedangkan pulangnya sekitar jam 21.00 WIB sesampai dirumah sekitar jam 21.30 WIB (W1 S1 27/04:69).

Subjek kedua jam kerjanya dari jam 07.00 WIB-15.00 WIB sampai dirumah sekitar jam 16.00 WIB setelah itu berangkat kuliah jam 16.30 WIB. Sedangkan pulang kuliah sekitar jam 21.00 WIB sampai dirumah sekitar jam 21.30 WIB. Jika subjek kedua masuk kerja second maka jam kerjanya dari jam 15.00 WIB-23.00 WIB (W2 S2 19/05:111).

Dari hasil wawancara terhadap kedua subjek, dapat disimpulkan bahwa kedua subjek mengalami kendala pada kurangnya waktu untuk menyelesaikan skripsinya dikarenakan harus sambil bekerja.

\section{Rasa Malas Mengerjakan Skripsi dan Kurang Motivasi}

Melemahnya motivasi mahasiswa dalam menyelesaikan skripsi terjadi pada mahasiswa Jurusan Bimbingan Konseling dan Matematika di Universitas Riau Kepulauan, hal ini peneliti temukan melalui hasil observasi dan wawancara. Berdasarkan hasil observasi dan wawancara yang peneliti lakukan pada bulan April-Juni 2015,terdapat mahasiswa yang motivasinya rendah dan kurang perhatiannya terhadap skripsi yang mereka kerjakan. Seperti menunda-nunda mengerjakan revisiyang diberikan oleh dosenpembimbing serta ada juga yang belum melakukan penelitian. Hal itu disebabkan olehpermasalahan yang dihadapi mahasiswa itu sendiri, seperti kurangmengertinya mahasiswa dengan revisian yang diberikan oleh dosen pembimbing dan kurangnya pengetahuan mahasiswa terhadap referensi-referensi yang diperlukan untuk kelengkapan skripsinya.

\section{Dosen yang Susah Ditemui}

Kesulitan untuk bertemu dengan dosen pembimbing disebabkan dosen sibuk atau cuti ini jugamenjadi masalah dalam penyusunan skripsi.Dari hasil wawancara yang telah dilakukan, awalnya yang dirasakan pada subjek pertama yaitu AS, dia susah sekali untuk bimbingan face to face dengan dosen pembimbingnya yang disebabkan dosennya beralasan sedang sibuk. Susahnya untuk bertemu dengan dosen bisa jadi disebabkan kurangnya komunikasi antara mahasiswa dan dosen, waktu yang kurang cocok, misalnya mahasiswa yang bisa bimbingan pada hari ini tetapi belum tentu dosennya juga bisa pada hari ini. Tetapi pada wawancara yang kedua subjek mengatakan bahwa sudah tidak ada masalah lagi dengan dosen pembimbingnya karena dosennya sudah bisa ditemui dirumahnya.

\section{Susah Membagi Waktu}

Masalah mengatur waktu atau membagi waktu sepertinya menjadi kendala terbesar dalam menyelesaikan skripsi. Target waktu mengerjakan skripsi yang semula harus selesai dalam waktu kurang dari enam bulan menjadi lebih dari enambulan jika mahasiswa tidak bisa mengatur waktu dengan baik.

Dari hasil wawancara yang telah dilakukan, dapat disimpulkan bahwa subjek kedua dari jam 07.00 WIB-15.00 WIB sampai dirumah sekitar jam 16.00 WIB setelah itu berangkat kuliah jam 16.30 WIB. Sedangkan pulang kuliah sekitar jam 21.00 WIB sampai dirumah sekitar jam 21.30 WIB. Jika subjek kedua masuk kerja second maka jam kerjanya dari jam 15.00 WIB-23.00 WIB sampai dirumah sekitar jam 23.30 WIB. Akibat dari kurang nya waktu untuk mengerjakan skripsi itu adalah lamanya proses pembuatan skripsi karena menunda-nunda dalam menyelesaikan skripsi.

\section{Kelelahan Bekerja}

Kelelahan yang terus menerus terjadi setiap hari akan berakibat terjadinya kelelahan kronis. Perasaan lelah tidak saja terjadi sesudah bekerja pada sore hari,tetapi juga selama bekerja, bahkan sebelum bekerja. Perasaan lesu tampak sebagai suatu gejala. Gejala psikis ditandai dengan perbuatan anti sosial dan perasaan tidak cocok dengan sekitar, sering depresi, kurangnya

\footnotetext{
* Nur Etika E-mail addres: icha.bk@gmail.com

* Wilda Fasim Hasibuan Telp. 081390001757 E-mail addres: wildahasibuan@,hotmail.com
} 
tenaga serta kehilangan inisiatif. Gejala psikis ini sering disertai kelainan psikolatis seperti sakit kepala,vertigo, gangguan pencernaan, tidak dapat tidur dan sebagainya.

Kelelahan kronis demikian disebut kelelahan klinis. Hal ini menyebabkan tingkat absentismeakan meningkat terutama mangkir kerja pada waktu jangka pendek disebabkan kebutuhan istirahat lebih banyak atau meningkatnya angka sakit. Kelelahanklinis terutama terjadi pada mereka yang mengalami konflik mental atau kesulitan psikologis. Selain itu sikap negatif terhadap kerja, dan perasaan terhadap atasan atau lingkungan kerja memungkinkan faktor penting dalam sebab ataupun akibat.

Dari hasil wawancara yang telah dilakukan, dapat disimpulkan bahwa subjek mengalami kelelahan karena bekerja lebih dari delapan jam per hari,belum lagi adanya lembur jika pekerjaan masih banyak yang belum terselesaikan di perusahaan. Sehingga hal ini membuat kondisi tubuh menurun dan juga terlalu banyak hal yang harus dikerjakan tetapi tidak adanya pengaturan waktu secara benar dan tersusun. Pada awalnya subjek mengalami kelelahan fisik, tetapi lama kelamaan menjadi lelah pada psikis subjeksehingga menghambat subjek dalam menyelesaikan skripsi nya.

\section{Waktu Istirahat tidak cukup}

Istirahat dan tidur merupakan dasar yang dibutuhkan oleh semua orang. Untuk dapat berfungsi secara normal, maka setiap orang memerlukan istirahat dan tidur yang cukup. Pada kondisi istirahat dan tidur, tubuh melakukan proses pemulihan untuk mengembalikan stamina tubuh hingga berada dalam kondisi yang optimal. Setiap individu mempunyai kebutuhan istirahat dan tidur yang berbeda. Pola istirahat dan tidur yang baik dan teratur memberikan efek yang bagus terhadap kesehatan. Namun dalam keadaan sakit, pola tidur seseorang biasanya terganggu.

Waktu istirahat yang tidak cukup, dapat mempengaruhi kinerja tubuh manusia. Dari hasil wawancara yang telah dipaparkan diatas, dapat disimpulkan bahwa subjek kedua merasa kurang waktu untuk istirahat karena jam kerja dia yang tidak pasti, terkadang masuk pagi, terkadang masuk malam. Pergantian waktu inilah yang menyebabkan kondisi fisik subjek yang menurun. Seperti sakit kepala, flu dan terkadang kurangnya nafsu makan.

9. Kurang Biaya

Biaya adalah semua pengorbanan yang perlu dilakukan untuk suatu proses produksi, yang dinyatakan dengan satuan uang menurut harga pasar yang berlaku, baik yang sudah terjadi maupun yang akan terjadi. Dari hasil wawancara yang telah dilakukan, dapat disimpulkan bahwa subjek kedua mengalami masalah pada kurang biaya yang dikarenakan terlalu banyak pengeluaran yang tak terduga misalnya orang tua sakit, pembayaran uang ujian mau pun untuk pembayaran lain yang serba mendadak, tugas yang harus diprint dengan segera serta untuk memenuhi kebutuhan subjek.

Keterbatasan dana untuk penelitian juga dapat mempengaruhi mahasiswa dalam penyusunan skripsinya. Akibatnya skripsinya itu akan ditunda-tunda sehingga tidak selesai tepat pada waktunya. Agar tidak terjadi seperti itu alangkah lebih baik nya mulai dari sekarang mencoba untuk menabung dan adakan planning untuk kebutuhan yang akan mendatang dengan sebaik-baik mungkin.

\section{Tidak Konsentrasi}

Konsentrasi adalah pemusatan pemikiran kepada suatu objek tertentu. Semua kegiatan kita membutuhkan konsentrasi. Dengan konsentrasi kita dapat mengerjakan pekerjaan lebih cepat dan dengan hasil yang lebih baik. Karena kurang konsentrasi hasil pekerjaan biasanya tidak dapat maksimal dan diselesaikan dalam waktu yang cukup lama. Oleh karena itu konsentrasi sangat penting dan perlu dilatih. Pikiran kita tidak boleh dibiarkan melayang-layang karena dapat menyebabkan gangguan konsentrasi. Pikiran harus diarahkan kesuatu titik dalam suatu pekerjaan. Dengan begitu pikiran kita makin hari akan semakin kuat.

Salah satu penyebab seseorang mengalami gangguan konsentrasi adalah karena orang tersebut gemar melamun secara berlebihan. Ketika seseorang melamun maka pikirannya akan melayang-layang sehingga kekuatan konsentrasinya menjadi lemah. Prilaku ini harus secepatnya dicegah karena jika hal ini dibiarkan terlalu lama maka orang tersebut akan menjadi gagal dalam mencapai cita-citanya. Tips konsentrasi ini memang berat dilakukan dan memerlukan kesabaran karena melatih konsentrasi membutuhkan waktu yang cukup lama. Tapi dengan keyakinan kita pasti dapat melakukannya dan keluar dari gangguan konsentrasi.

\footnotetext{
* Nur Etika E-mail addres: icha.bk@gmail.com

* Wilda Fasim Hasibuan Telp. 081390001757 E-mail addres: wildahasibuan@hotmail.com
} 
Dari hasil wawancara kepada subjek kedua yang telah dipaparkan diatas, dapat disimpulkan bahwa subjek mengalami hal tersebut. Yaitu tidak konsentrasi karena akibat dari lelah. Biasanya mahasiswa tidak konsentrasi pada penyusunan skripsi yang disebabkan oleh tidak fokus nya pada tugas akhir yang dikerjakan. Sebisa mungkin mahasiswa harus mengurangi kegiatan atau masalah atau hal-hal lain yang tidak berkaitan dengan tugas akhir karena hal itu bisa mengurangi konsentrasi terhadap apa yang sedang dikerjakan.

Supaya konsentrasi menjadi kuat, maka kita perlu melatih konsentrasi. Pikiran perlu diarahkan hanya pada satu titik saja pada suatu waktu. Jika pikiran melayang maka orang tersebut harus diingatkan dan diarahkan agar kembali ke titik semula. Cara seperti ini memang agak sulit dilakukan dan memerlukan kesabaran karena melatih konsentrasi membutuhkan waktu yang cukup lama. Tapi dengan keyakinan kita pasti bisa melakukannya dan keluar dari gangguan konsentrasi.

\section{Penutup}

Berdasarkan informasi yang didapat dari hasil penelitian dan pembahasan ada beberapa kendala yang dialami oleh mahasiswa semester delapan diUnrika Batam dalam penyusunan Tugas Akhir Skripsi dapat ditarik kesimpulan sebagai berikut:

1. Adanya kebingungan mahasiswa dalam menentukan judul tugas akhir skripsi.

2. Kurangnya referensi dan buku pendukung yang tersedia di perpustakaan.

3. Keterbatasan dana atau kurangnya biaya untuk penelitian.

4. Adanya waktu istirahat yang tidak cukup.

5. Kemalasan mahasiswa dalam mengerjakan tugas akhir skripsi sehingga kurangnya motivasi dari dalam diri mahasiswa.

6. Kesulitan untuk bertemu dengan dosen pembimbing.

7. Adanya kesulitan mahasiswa dalam mengelola waktu untuk mengerjakan tugas akhir skripsi.

8. Tidak konsentrasi dalam pembuatan skripsi.

9. Kurangnya waktu untuk mengerjakan skripsi.

10. Adanya rasa lelah yang diakibatkan dari bekerja sehingga membuat mahasiswa tidak semangat untuk mengerjakan skripsi.

Berdasarkan penelitian yang telah dilakukan dan informasi yang telahdiperoleh, maka peneliti dapat memberikan saran sebagai berikut:

\section{Bagi Subjek Penelitian}

Memperbaiki cara berpikir dan konsep diri yang negatif dari keduasubjek, dengan cara selalu berfikir positif terhadap apa yang kita kerjakan. Tuntutan tidak harus ditinggalkan ataupun dibiarkan, tetapi dikerjakan dengan sebaik mungkin agar selesai tepat pada waktunya.

2. Bagi Mahasiswa pada Umumnya

a. Dapat mengetahui apa saja permasalahan yang timbul dalam penyusunan skripsi. Mereka dapat mengantisipasi jika mengalami rasa malas atau pun tidak sama sekali tidak ingin mengerjakan skripsi.

b. Perbanyak membaca agar memiliki wawasan yang luas terhadap penyelesaian skripsinya dan tidak akan mengalami kesusahan dalam penyusunan skripsi.

3. Bagi Orang Tua

a. Memberikan motivasi kepada putra-putrinya yang sedang menyelesaikan skripsi, sehingga mampu menyelesaikan skripsi tepat pada waktunya.

b. Menjadi sahabat bagi anak dan mengetahui kebutuhan anaksehingga anak akan terbuka mengenai keadaan diri dan orang tua dapat mengarahkan anak pada hal-hal yangpositif.

4. Bagi Peneliti Selanjutnya

a. Supaya kedepannya bisa mendapatkan referensi yang lebih dari sekarang.

b. Dapat mencari lebih banyak lagi penelitian yang meneliti tentang masalah mahasiswa yang sedang menyelesaikan skripsi.

c. Dapat menggali masalah-masalah apa saja yang terjadi pada mahasiswa dalam menyelesaikan skripsinya.

* Nur Etika E-mail addres: icha.bk@gmail.com

* Wilda Fasim Hasibuan Telp. 081390001757 E-mail addres: wildahasibuan@hotmail.com 


\section{Daftar Pustaka}

Hariwijaya, M. Metodologi Dan Teknik Penulisan Skripsi, Tesis, dan Disertasi. Elematera Publishing, Yoyakarta.

Patilima, Hami.. (2005). Metode Penelitian Kualitatif. Bandung: Alfabeta.

Pujosuwarno, Sayekti.. (1994). Bimbingan Dan Konseling Keluarga, Yogyakarta : Menara Mas Offset.

Sugiyono.. (2012). Memahami Penelitian Kualitatif. Bandung : Alfabeta.

. (2013).Metode Penelitian Kuantitatif Kualitatif dan R\&D. Bandung: Alfabeta.

* Nur Etika E-mail addres: icha.bk@gmail.com

* Wilda Fasim Hasibuan Telp. 081390001757 E-mail addres: wildahasibuan@hotmail.com 